\begin{tabular}{|l|l|l||}
\hline \multicolumn{2}{|c|}{ PublisherInfo } \\
\hline \hline PublisherName & $:$ & BioMed Central \\
\hline \hline PublisherLocation & $:$ & London \\
\hline \hline PublisherImprintName & $:$ & BioMed Central \\
\hline \hline
\end{tabular}

\title{
Brain damage in sepsis
}

\begin{tabular}{|l|l|l||}
\hline \multicolumn{2}{|c|}{ ArticleInfo } \\
\hline \hline ArticleID & $:$ & 4224 \\
\hline \hline ArticleDOI & $:$ & $10.1186 /$ ccf-2000-6560 \\
\hline \hline ArticleCitationID & $:$ & 6560 \\
\hline \hline ArticleSequenceNumber & $:$ & 83 \\
\hline \hline ArticleCategory & $:$ & Paper Report \\
\hline \hline ArticleFirstPage & $:$ & 1 \\
\hline \hline ArticleLastPage & $:$ & 3 \\
\hline \hline & & RegistrationDate : 2000-10-9 \\
\hline ArticleHistory & $:$ & OnlineDate \\
\hline \hline ArticleCopyright & $:$ & Current Science Ltd2000-10-9 \\
\hline \hline ArticleGrants & $:$ & \\
\hline \hline ArticleContext & $:$ & 1305422 \\
\hline \hline
\end{tabular}


Aff1 Southampton General Hospital, UK

\section{Keywords}

Brain damage, cerebral oxygen balance, cerebral perfusion pressure, cytotoxic brain oedema, IL-6, sepsis, septic encephalopathy, TNF- $\alpha$.

\section{Comments}

This is an interesting paper for two reasons. First, an instrumented animal model of septic encephalopathy is described and second the authors demonstrate that histological brain damage occurs in severe sepsis. These findings strongly suggest that cerebral oedema, cell damage and death occur in sepsis, even when mean arterial pressure (MAP) and oxygen delivery are unchanged. Although in this study there was a slight reduction in cerebral perfusion pressure (due to central veneus pressure [CVP] increasing) there was no fall in the oxygenation of blood from the saggital sinus, infering that oxygen delivery was maintained. Microabscesses were found in the brain of only one of the nine septic pigs, suggesting that direct infection of the brain was not the cause. As tumour necrosis factor (TNF)- $\alpha$ levels were raised in the cerebrospinal fluid (CSF), and intracerebral TNF- $\alpha$ is known to cause encephalopathy and death, this seems to be the likely culprit.

\section{Introduction}

The aim of this study was to investigate sepsis-induced brain damage in a porcine model.

\section{Methods}

- Twenty-one pigs were studied and instrumented with a femoral arterial catheter, flow probe around the pulmonary artery, central venous cannula, portal vein catheter and a cannula in the saggital sinus.

- The pigs were divided in to a control group $(\mathrm{n}=10)$ and a septic group $(\mathrm{n}=11)$. 
- All pigs were sedated with propofol and fentanyl and ventilated for 4 days.

- Septic pigs had Escherichia coliinfused via the portal catheter to induce sepsis.

- Serum and CSF samples were taken for interleukin (IL)- 6 and TNF- $\alpha$ assays.

- After 4 days the pigs were killed and their brains sectioned for histological examination.

\section{Results}

Five pigs were excluded from the analysis leaving nine septic and seven control animals. All septic animals (and no controls) developed signs of sepsis. Norepinepherine was required for both control and septic animals but the requirement was significantly higher in the septic group. Two pigs in the control group showed signs of minor histological changes. All the pigs in the septic group showed moderate to severe perivascular oedema and cell damage. There were also brain purpura in most animals. Microabscesses were found in one animal. TNF- $\alpha$ and IL-6 levels increased significantly in the serum and CSF of the septic animals.

\section{References}

1. Bogdanski R, Blobner M, Becker I, Hanel F, Fink H, Kochs E: Cerebral histopathology following portal venous infusion of bacteria in a chronic porcine model. Anesthesiology. 2000, 93: 793-804. 